\title{
Workplace Activity in Health Professionals Exposed to Chemotherapy Drugs: An Otoneurological Perspective
}

\author{
Natália Martinez Fernandes ${ }^{1}$ Isadora Gonçalves Pelissari ${ }^{1}$ Licia Assunção Cogo ${ }^{2}$ \\ Valdete Alves Valentins dos Santos Filha ${ }^{1}$ \\ ${ }^{1}$ Department of Speech-Language Pathology and Audiology, \\ Universidade Federal de Santa Maria, RS, Brazil \\ 2 Post-Graduation Student, Department of Speech-Language Pathology \\ and Audiology, Universidade Federal de Santa Maria, RS, Brazil \\ Address for correspondence Natália Martinez Fernandes, Department \\ of Speech Language Pathology and Audiology, Universidade Federal de \\ Santa Maria, Avenida Roraima 1000, Santa Maria, RS 97105900, Brazil \\ (e-mail: nataliafernandes.fono@gmail.com).
}

Int Arch Otorhinolaryngol 2016;20:331-338.

\begin{abstract}
Keywords

- hearing

- drug therapy

- occupational health services

- vestibular function tests

- dizziness
\end{abstract}

\section{Introduction}

Cancer is the name given to different diseases which resemble one another by uncontrolled growth of abnormal cells, with invasive potential and originated by multifactorial causes. ${ }^{1}$ The disease is considered the second leading cause of death worldwide and is considered a public health problem. $^{2}$

received

September 22, 2015 accepted

November 24, 2015

published online

February 12, 2016
Treatment with chemotherapy, a systemic treatment modality, is considered the major option for cancer control. ${ }^{3}$ Chemotherapeutic, antineoplastic, or cytostatic agents are drugs used, in combination or alone, with the aim of eliminating neoplasms. These drugs work on the cell level, interfering in the process of cell growth and division. Most of these drugs are not selective in destroying only tumor cells, and, therefore, also interfere in normal cells. ${ }^{4}$

Copyright $\odot 2016$ by Thieme Publicações License terms Ltda, Rio de Janeiro, Brazil

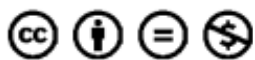


As the number of cancer cases increases, so does the demand for professionals involved in the care and treatment of these patients. This, in turn, increases the occupational risks to which these professionals are exposed.

The handling of antineoplastic drugs is considered the major occupational exposure to chemical agents in hospitals, and involves a high risk of accidents and work diseases, ${ }^{5}$ affecting mostly pharmacists, nurses, and nurse technicians, who are constantly involved in preparing and administrating these drugs. This is because the inhalation of aerosol and percutaneous absorption of residues and particles are the main routes of exposure. ${ }^{6}$ Such agents may go unnoticed, leading to an immediate or delayed health-disease process ${ }^{7}$ to the worker.

Chemotherapeutic agents have been a constant object of research in the areas of pharmacology and nursing. ${ }^{5-11}$ However, organic reactions after exposure to antineoplastic drugs are still unclear. It is believed that these drugs can harm workers' health due to their toxicity, and may cause undesirable and irreversible side effects when exposed and manipulated without safety measures.

According to the literature, ${ }^{12}$ gases and vapors present in the hospital environment affect the organism, causing various reactions, such as weakness, fainting, drowsiness, seizure, vomiting, headache, vision disturbances, tremor, cough, conjunctival tearing, and dizziness.

Auditory and vestibular disorders can result from the exposure to ototoxic drugs and noise. ${ }^{13}$ The contact with ototoxic drugs, considered cochleo-toxic (affect hearing) and vestibulartoxic (affect balance), ${ }^{14}$ can lead to functional changes or cell damage in the inner ear (anterior and posterior labyrinth), ${ }^{15}$ acting in the brainstem and/or central nervous system. ${ }^{15,16}$

Hearing is a complex sense that enables us to identify, locate, and process sounds, allowing people to do activities that range from monitoring danger signals and understanding speech to appreciating music. For this system to function properly, all of the path the sound will travel through has to be healthy, from the outer ear to the central auditory pathways. ${ }^{17}$ Hearing damage from ototoxicity is characterized by cochlear, bilateral, symmetrical, and irreversible hearing loss. It begins by the high frequencies, and its degree depends on the concentration of the ototoxic element. There may also be tinnitus and dizziness. ${ }^{18}$

In addition to hearing, balance can also be affected by chemotherapy. The vestibular system is responsible for informing about the position and movement of the head, providing us with sense of balance, which assists in the coordination of head and eye movements, as well as in body posture adjustments. When its function is disrupted, unpleasant sensations can occur, such as dizziness, nausea, and a feeling of lack of balance with uncontrollable eye movements. ${ }^{19}$

Brazil's Ministry of Labor's Regulatory Standard number 9 (NR-9) establishes the obligation of the preparation and implementation of Environmental Risk Prevention Programs (ERPP), to preserve the health and integrity of workers. Among the actions of the program are the evaluation and control of risks in the work environment. ${ }^{20}$

To monitor the ototoxicity in hearing as well as in body balance, it is believed that different procedures can be used.
Audiometry is an effective method, because it assesses the auditory pathway quantitatively. Otoacoustic emissions may also contribute, as they directly evaluate the outer hair cells of the cochlea, working as a predictor for hearing loss. ${ }^{21}$ On the other hand, the vectoelectronystagmography, crucial in otoneurological evaluation, provides data about the vestibulo-oculomotor function and its correlation with the brainstem, cerebellum and other connections to the central nervous system. $^{22}$

Another important aspect that should be considered in relation to studies involving chemotherapy handling are the ways to reduce occupational exposure to these agents, in particular the adoption of procedures for prevention and the use of Personal Protective Equipment - PPE (googles, masks, latex gloves, and apron), essential during every stage of drug manipulation. ${ }^{23}$

The focus of studies concerning the effect of chemotherapy is generally patients in oncological treatment, that is, those who receive medication, disregarding the workers who apply it, and are exposed to the drugs on a daily basis.

Thus, the aim of this study was to investigate the health conditions of the auditory and vestibular systems of health care professionals exposed to chemotherapeutic drugs, through conventional hearing evaluation, otoacoustic emissions by transient stimuli, and computerized vectoelectronystagmography; as well as to identify the use of Personal Protective Equipment, connecting it to the results obtained.

\section{Methods}

This was an observational, descriptive, cross-sectional study, which used a quantitative method.

This study was approved by the Research Ethics Committee (CEP) of Universidade Federal de Santa Maria, in section 04.10.2013, under protocol number 306039 , and is part of a project entitled Integrated Otoneurological Evaluation in Individuals Assisted by a University Hospital. The study was conducted at the Ambulatory of Otoneurology - Balance and Audiology sector of a University Hospital.

The sample consisted of 33 health professionals in the Nursing and Pharmacy sectors of a University Hospital, exposed to chemotherapy, with ages ranging from 21 to 60 years old, male and female, after agreeing with participating in the research by reading and signing the Free and Informed Consent.

The investigation adopted the following inclusion criteria: being in contact with antineoplastic agents - injectable chemotherapy drugs and/or pills - not necessarily having complaints regarding hearing and/or balance disorders. The exclusion criteria involved individuals with neurological, or cognitive impairments, middle ear disorders, and/or significant visual impairments that could prevent vestibular and hearing evaluation.

We tested the health professionals by means of audiological evaluations, composed by anamnesis, to obtain previous and current medical and occupational history of the worker concerning auditory and vestibular complaints, data regarding the history of exposure to chemicals and use of Personal 
Protective Equipment (PPE). The patients underwent a visual inspection of the external acoustic meatus using a Heidji otoscope; Pure tone audiometry at frequencies of 250 to $8000 \mathrm{~Hz}$ by air conduction (AC), and 500 to $4000 \mathrm{~Hz}$ by bone conduction $(B C)$ (in frequencies with auditory thresholds of air conduction above $25 \mathrm{~dB}$, in both ears); Logoaudiometry - Speech Recognition Threshold (SRT) and Speech Recognition Percentage Index (SRPI), done in an acoustic booth with a pair of TDH-39P headphones (Vitasons, Porto Alegre, Brazil), using a digital two-channel Otometrics audiometer, model Itera II (Telephonics, Taastrup, Denmark), calibrated according to the ANSI-69 standard; Acoustic Immitance Measures (tympanometry with a $226 \mathrm{~Hz}$ probe tone, and research of the acoustic reflex of the contralateral stapedius muscle - dBNS with research of the thresholds at 0.5; 1; 2 and $4 \mathrm{kHz}$, using the Interacoustic middle ear analyzer, model AT235 (Middelfart, Denmark), and Transient evoked otoacoustic emissions (TEOAEs), beginning by the right ear. We used parameters for analysis proposed by the authors, ${ }^{24}$ that is, non-linear clicks with regular pulses lasting 80 microseconds ( $\mu \mathrm{s})$, polarity rarefied, in a series of 260 stimuli in eight-clicks blocks each, with repetition frequency of 50 cycles per second. As for the spectrum of emissions, the standard stimulus contains energy distributed in the frequency bands of $0.7 ; 1.0 ; 1.4 ; 2.0 ; 2.8$; and $4 \mathrm{kHz}$, using the cochlear analyzer Otoread in an acoustic booth.

Then, were evaluated the professionals in terms of vestibular assessment through the computerized Vectoelectronystagmography (VNG), after previous preparation. Initially, their skin was cleaned with alcohol, and then the electrodes were fixed by means of electrolytic paste and adhesive tape (micropore tape) in the periorbital region, disposed as an isosceles triangle: one electrode on each outer eyelid angle of the eye, the other on the front (earth electrode) and the last $2 \mathrm{~cm}$ above the glabela (active electrode), enabling the recording of horizontal, vertical, and oblique movements. The individuals were seated in a swivel chair, $1 \mathrm{~m}$ to the Led's bar. The VNG comprised calibration (horizontal and vertical); research of spontaneous nystagmus with open and closed eyes; research of semispontaneous or directional nystagmus (right, left, top, and bottom); of pendular tracking; of optokinetic nystagmus (clockwise and counterclockwise); of per-rotatory nystagmus or decrescent rotatory pendular test (head $30^{\circ}$ forward), and; research of post-caloric nystagmus with stimulus of water at $30^{\circ}$ and $44^{\circ} \mathrm{C}$, according to the proposed criteria. ${ }^{22}$ For the vestibular-oculomotor evaluation, we used the Contronic VNG computerized system, model $\mathrm{SCV}$, version 5.0, and Nistagmus software.

At the end of the collection, the data were tabulated in an online Excel spreadsheet and analyzed statistically. Concerning the statistical method used, we performed a descriptive critical analysis on percentage, mean, standard deviation, and median values, as well as the Fisher's exact test and chisquare statistical analysis.

\section{Results}

The sample consisted of 33 health professionals exposed to chemotherapy agents, of whom $90.9 \%$ were female and $9.1 \%$ male, with an average age of 37.18 years ( \pm 13.20 ). The age group from 20 to 35 represented $54.54 \%$ of the population, $18.2 \%$ between 35 and 45 years, and between 50 and 60 years of age the percentage was $27.3 \%$, as there were no individuals in the age group between 45 and 50 years. 51.52\% of these professionals work in the field of pharmacy and $48.48 \%$ in nursing.

Considering the professionals exposed to chemotherapy agents working in the areas of nursing and pharmacy, $56.25 \%$ and $52.94 \%$ reported dizziness, respectively. Upon Chi-square test, there was no statistically significant difference $(p=0.84)$.

Regarding the variable time of service exposed to chemotherapy agents, $51.51 \%$ work for less than five years in the field, considering this as the most frequent occurrence; with an average time of 10.66 years $( \pm 10.54)$.

Concerning the presence of dizziness, $54.54 \%$ had some type of dizziness, from which $61.12 \%$ was non-rotatory and $38.88 \%$ rotatory, in addition to $75.75 \%$ of neurovegetative symptoms. The main extra-hearing complaints reported in the anamnesis were anxiety (69.7\%), stress (56.6\%), nervousness (51.5\%), headache (45.5\%), and depression (30.3\%).

In the audiological assessment, $96.97 \%$ of the participants had hearing thresholds within the normal range according to the tritone average $(0.5,1$ and $2 \mathrm{kHz})$, and $3.03 \%$ had mild sensorineural hearing loss; identifying notch configuration in $75.75 \%$ of the individuals; $40 \%$ notched at a frequency of $6 \mathrm{kHz}$ (eight RE, two LE), 24\% at a frequency of $4 \mathrm{kHz}$ (three $\mathrm{RE}$, three LE), and 36\% in both ears at $6 \mathrm{kHz}$. All evaluated subjects (100\%) presented tympanometry curve type A, and the contralateral acoustic reflex was present in $87.87 \%$ in the right ear and $93.93 \%$ in the left ear. In addition, there were otoacoustic emissions by transient stimuli in $100 \%$ of the assessed individuals.

- Table 1 indicates the distribution of absence and presence of notch in the audiometric configuration of the workers with and without dizziness complaint.

The distribution of presence and absence of notch in the audiometric configuration of Pharmacy and Nursing workers is shown in - Table 2.

The association between the occurrence of normal and abnormal results in research of the post-caloric nystagmus and the presence and absence of notch in the audiometric configuration is identified in - Table 3.

In the vestibular assessment, 31 professionals were submitted to VNG. From the results, $100 \%$ of the participants had regular calibration, absence of spontaneous and semi-spontaneous nystagmus with eyes open and closed; $83.87 \%$ showed horizontal pendular tracking type I, and 16.13\% type II; 70.97\% showed vertical pendular tracking type I, $16.13 \%$ type II, and $12.90 \%$ of the subjects type III; symmetry was present in $90.32 \%$ in the optokinetic nystagmus test, and $96.77 \%$ in the decrescent rotatory pendular test. In the research of post-caloric nystagmus, we observed the diagnosis of normal reflexes in $74.20 \%$ of the participants, hyperreflexia in $12.90 \%$, labyrinth predominance in $9.68 \%$, and $3.22 \%$ with hyporreflexia. From the analysis of the results found in vestibular tests, we identified that $74.20 \%$ of the 
334 Workplace Activity in Health Professionals Exposed to Chemotherapy Drugs Fernandes et al.

Table 1 Distribution of absence and presence of notch in the audiometric configuration in workers with and without dizziness

\begin{tabular}{|c|c|c|c|c|}
\hline Group & $\begin{array}{l}\text { Notch absence } \\
\mathrm{N}(\%)\end{array}$ & $\begin{array}{l}\text { Notch presence } \\
\mathrm{N}(\%)\end{array}$ & $\begin{array}{l}\text { Total } \\
\text { N (\%) }\end{array}$ & p-value \\
\hline With dizziness & $7(87.50)$ & $11(44.00)$ & $18(54.54)$ & \\
\hline Without dizziness & $1(12.50)$ & $14(56.00)$ & $15(45.45)$ & \multirow[t]{2}{*}{$0.04^{*}$} \\
\hline Total & $8(100.00)$ & $25(100.00)$ & $33(100.00)$ & \\
\hline
\end{tabular}

Fisher's exact test ${ }^{*} p<0.05$.

Table 2 Association between the occurrence of normal and abnormal results of the post-caloric nystagmus and the presence and absence of notch in the audiometric configuration

\begin{tabular}{|l|l|l|l|l|}
\hline \multirow{2}{*}{ Group } & Notch & $\begin{array}{l}\text { Total } \\
\text { N (\%) }\end{array}$ & p-value \\
\cline { 2 - 4 } & $\begin{array}{l}\text { YES } \\
\text { N (\%) }\end{array}$ & $\begin{array}{l}\text { NO } \\
\text { N (\%) }\end{array}$ & \\
\hline Normal & $19(82.60)$ & $23(74.19)$ & 2374,19 & 0.15 \\
\hline Altered & $4(17.40)$ & $8(25.81)$ & 825,81 \\
\hline Total & $23(100.00)$ & $31(100.00)$ & 31100,00 \\
\hline
\end{tabular}

Fisher's exact test.

subjects were diagnosed as within the normal range, one (12.90\%) subject presented peripheral vestibular deficit dysfunction, and another (12.90\%), vestibular dysfunction.

- Table 4 shows the distribution of occurrence of normal and abnormal results in the research of post-caloric nystagmus in pharmacy and nursing workers.

Considering the health professionals investigated, we observed that $90.9 \%$ use some kind of Personal Protective Equipment (PPE): 90.9\% wear gloves; 84.84\% wear aprons; $69.69 \%$ wear common masks; $24.24 \%$ wear caps; $21.21 \%$ wear activated coal masks, and $9.09 \%$ wear goggles.

We present the association between the occurrence of normal and abnormal results in the research of post-caloric nystagmus and whether workers of pharmacy and nursing wear coal masks and gloves or not in -Table 5 .

- Table 6 shows the association between the occurrence of notch in the audiometric configuration and whether workers of pharmacy and nursing wear coal masks and gloves or not.

\section{Discussion}

The population of this study was mostly female. This is similar to the data obtained by other authors, ${ }^{5-10}$ who had $63.3 \%$,
$70 \%$, and $88 \%$ of female subjects, respectively. Health practices are closely related to the act of caring, and this is historically linked to the female gender; therefore, it is natural to find a higher incidence of women in participants of the health sector, especially in nursing. ${ }^{5}$

As regards to age, there was a prevalence of young adults, with $70 \%$ of the population aged $20-35$ years old. ${ }^{5}$ Another author ${ }^{8}$ studied a 21-47-year-old age group in this occupation. The study's data are similar to those found in our study.

In the current study, health professionals exposed to chemotherapy agents are categorized in the areas of pharmacy and nursing, corroborating a study ${ }^{9}$ that identified such as the areas with higher exposure to such chemical agents in a hospital.

As for the duration of exposure to chemotherapy drugs, we observed in this study that most professionals have been working in the field for less than five years. Such results corroborate other studies found in the literature, ${ }^{8}$ in which the time of professional experience of the nursing staff in the chemotherapy sector was higher than two years (76.70\%). In contrast, another study ${ }^{10}$ found that $67 \%$ of the nurses working in the chemotherapy sector had been in the job for more than five years.

Table 3 Distribution of the presence and absence of notch in the audiometric configuration on workers of Pharmacy and Nursing

\begin{tabular}{|c|c|c|c|c|}
\hline \multirow[t]{2}{*}{ Group } & \multicolumn{2}{|l|}{ Notch } & \multirow{2}{*}{$\begin{array}{l}\text { Total } \\
\text { N (\%) }\end{array}$} & \multirow[t]{2}{*}{ p-value } \\
\hline & $\begin{array}{l}\text { YES } \\
\text { N (\%) }\end{array}$ & $\begin{array}{l}\text { NO } \\
\text { N (\%) }\end{array}$ & & \\
\hline Pharmacy & $15(60.00)$ & $2(25.00)$ & $17(51.51)$ & \multirow[t]{3}{*}{0.11} \\
\hline Nursing & $10(40.00)$ & $6(75.00)$ & $16(48.49)$ & \\
\hline Total & $25(100.00)$ & $8(100.00)$ & $33(100.00)$ & \\
\hline
\end{tabular}

Fisher's exact test. 
Table 4 Distribution of occurrence of normal and abnormal results in the post-caloric nystagmus of workers of Pharmacy and Nursing

\begin{tabular}{|l|l|l|l|l|}
\hline Group & $\begin{array}{l}\text { Normal } \\
\text { N (\%) }\end{array}$ & $\begin{array}{l}\text { Altered } \\
\text { N (\%) }\end{array}$ & $\begin{array}{l}\text { Total } \\
\text { N (\%) }\end{array}$ & $p$-value \\
\hline Pharmacy & $13(56.52)$ & $2(25.00)$ & $15(48.39)$ & 0.21 \\
\hline Nursing & $10(43.48)$ & $6(75.00)$ & $16(51.61)$ \\
\hline Total & $23(100.00)$ & $8(100.00)$ & $31(100.00)$ & \\
\hline
\end{tabular}

Fisher's exact test.

Table 5 Association between the occurrence of normal and abnormal results in the post-caloric nystagmus and the use or not of coal masks and gloves by workers of Pharmacy and Nursing

\begin{tabular}{|c|c|c|c|c|c|}
\hline PPE & Group & $\begin{array}{l}\text { Normal } \\
\mathrm{N}(\%)\end{array}$ & $\begin{array}{l}\text { Altered } \\
\mathrm{N}(\%)\end{array}$ & $\begin{array}{l}\text { Total } \\
\mathrm{N}(\%)\end{array}$ & p-value \\
\hline \multirow[t]{2}{*}{ Coal Mask } & Yes & $7(30.43)$ & $0(0.00)$ & $7(22.58)$ & \multirow[t]{3}{*}{0.14} \\
\hline & No & $16(69.57)$ & $8(100.00)$ & $24(77.42)$ & \\
\hline \multicolumn{2}{|l|}{ Total } & $23(100.00)$ & $8(100.00)$ & $31(100.00)$ & \\
\hline \multirow[t]{2}{*}{ Glove } & Yes & 22 (96.65) & $6(75.00)$ & $28(90.32)$ & \multirow[t]{3}{*}{0.15} \\
\hline & No & $1(4.35)$ & $2(25.00)$ & $3(9.68)$ & \\
\hline \multicolumn{2}{|l|}{ Total } & $23(100.00)$ & $8(100.00)$ & $31(100.00)$ & \\
\hline
\end{tabular}

Fisher's exact test.

Abbreviations: PPE, personal protective equipment.

Table 6 Association between the occurrence of notch in the audiometric configuration and the use or not of coal masks and gloves by workers of Pharmacy and Nursing

\begin{tabular}{|c|c|c|c|c|c|}
\hline PPE & Group & $\begin{array}{l}\text { Notch/yes } \\
\mathrm{N}(\%)\end{array}$ & $\begin{array}{l}\text { Notch/no } \\
\mathrm{N}(\%)\end{array}$ & $\begin{array}{l}\text { Total } \\
\mathrm{N}(\%)\end{array}$ & p-value \\
\hline \multirow[t]{2}{*}{ Coal Mask } & Yes & $6(24.00)$ & $1(12.50)$ & $7(21.22)$ & \multirow[t]{3}{*}{0.65} \\
\hline & No & $19(76.00)$ & $7(87.50)$ & $26(78.78)$ & \\
\hline \multicolumn{2}{|l|}{ Total } & $25(100.00)$ & $8(100.00)$ & $33(100.00)$ & \\
\hline \multirow[t]{2}{*}{ Glove } & Yes & $25(100.00)$ & $5(62.50)$ & $28(84.84)$ & \multirow[t]{3}{*}{$0.01^{*}$} \\
\hline & No & $0(0.00)$ & $3(37.50)$ & $3(15.16)$ & \\
\hline \multicolumn{2}{|l|}{ Total } & $25(100.00)$ & $8(100.00)$ & $33(100.00)$ & \\
\hline
\end{tabular}

Fisher's exact test; * $p<0.05$.

Abbreviations: PPE, personal protective equipment.

There is a scarcity of epidemiological studies addressing the time of occupational exposure to chemotherapy agents that can cause hearing loss or balance disorders; however, research ${ }^{25}$ indicates that individuals in contact with ototoxic chemical products may begin to show hearing loss as early as two or three years of exposure to these substances, while noise exposure would take four to five years. According to that, the population of this study is already within the risk range, considering that hearing loss can be triggered by the ototoxic chemical process.

The current study also highlighted the prevalence of nonrotating dizziness associated with neurovegetative symptoms. In a study ${ }^{26}$ conducted with nurses who had direct contact with medications, solutions, antiseptics, chemother- apy agents, etc., dizziness complaints were reported, but not specified, and persisted even with the use of PPE. Regarding the neurovegetative symptoms, a study ${ }^{8}$ identified that $10 \%$ of the nurses evaluated showed symptoms such as nausea and heat in the face when in contact with the chemotherapy drug.

In the current study, there were extra-auditory complaints, shown in decreasing order herein: anxiety, stress, nervousness, headache, and depression. This corroborates research ${ }^{27}$ conducted with workers of a hospital, which found that headache was the fourth symptom related to work, pointing out the relationship between hospital work and extra-auditory complaints. Such symptoms can be observed either in the preparation or in the administration of antineoplastic drugs without the use of collective or personal 
protective equipment, which implies a significant and inappropriate absorption of such substances. $^{28}$

In the same study, ${ }^{28}$ risks caused by handling antineoplastic drugs result from the inherent toxicity of the drug and the time of exposure to them. Moreover, the authors report that the extra-auditory complaints can be compared with those presented by patients being treated with these substances.

In the present study, we observed that most professionals in nursing and pharmacy had complaints of dizziness. Despite the lack of studies showing the percentage of occurrence of dizziness in these occupations, it is important to highlight that occupational exposure to antineoplastic drugs can cause immediate (headache, vertigo, dizziness, and vomiting), or late effects (carcinogenesis, mutagenic, and teratogenic). ${ }^{29}$

Among the main drugs used by the population evaluated are carboplatin, cyclophosphamide, cisplatin, doxorubicin, gentamicin, vinblastine, fluorouracil, vincristine, among others. These drugs are causers of reactions that are toxic to the inner ear structures, and could harm the auditory and/or vestibular system, either centrally and/or peripherally. $^{15-30}$

The exposure to these drugs can cause various effects, including vertigo, which was observed in professionals responsible for the preparation or administration of antineoplastics without the use of protective equipment. ${ }^{9}$ The same author points out that the effects caused by the contact with these substances can be compared with those presented by patients undergoing antineoplastic treatment.

According to the literature, ${ }^{31}$ the use of aminoglycosides and platinum derivatives such as cisplatin have been pointed as the most common cause of permanent hearing loss by ototoxic drugs. The incidence of hearing loss induced by cisplatin ranges from three to $100 \%$ in the literature. This data does not differ from those of a study ${ }^{32}$ that evaluated children undergoing cisplatin treatment, and identified that ototoxic effects initially affect high frequencies, with subsequent impairment of medium and, subsequently, of low frequencies, according to the cumulative dose of the drug, characterizing the cisplatin-induced hearing loss as sensorineural, bilateral, symmetrical, and irreversible.

In the audiological evaluation of the current study, most workers presented hearing thresholds within the normal limits according to the tone average $(0.5,1$, and $2 \mathrm{kHz})$ and notch configuration in high frequencies.

When evaluating the hearing of patients undergoing treatment with cisplatin, authors ${ }^{33}$ state that hearing loss induced by the use of this drug can occur even after the interruption of the treatment, showing the prolonged and cumulative effect of chemotherapy in the human organism. This study also establishes the importance of the audiologic routine test battery in patients undergoing chemotherapy. Due to the intense exposure, it is understood that this monitoring should be expanded to professionals who come into contact with these substances.

In the present study, even though lowered tone thresholds were not found, the presence of notch could be identified as an indicator for taking control and prevention measures in relation to the damage caused by ototoxicity. For this reason, the auditory and vestibular monitoring is believed to be of great importance for early detection of the effects of ototoxicity on workers.

During the audiological assessment, we found a tympanometric curve of type A and contralateral acoustic reflex. Studies ${ }^{34,35}$ have shown that the majority of workers exposed to chemical agents have tympanometry curve of type $A$ in both ears; in $75 \%$ of subjects in the right ear, and $100 \%$ in the left ear, respectively; however, there was a prevalence of bilaterally absent contralateral acoustic reflexes.

Regarding transient otoacoustic emissions, we identified in this study that optoacoustic emissions by transient stimuli were present in the whole population studied, indicating normal cochlear function of outer hair cells. Similar results were found in $100 \%$ of the patients treated with cisplatin. ${ }^{31,32}$ Otoacoustic emissions (OAEs) are used to monitor hearing in individuals exposed to ototoxic drugs, ${ }^{36}$ since they could be a predictor for hearing loss in occupational cases. ${ }^{21}$

Concerning the distribution of presence or absence of a notch in the audiometric configuration of the workers with and without dizziness complaint, in addition to observing statistically significant differences, a positive association was found, since most individuals with dizziness complaints had notch configuration, indicating that there is an association of the facts in this population.

Regarding other associations focusing on clinical exams, no significant differences were found. However, the presence of notch in the hearing configuration could be observed regardless of occupation, as well as a higher percentage of normal results, while in the group of nursing workers there was a higher percentage of abnormal results, respectively; even though we observed no statistically significant difference. In both occupations, there was a higher percentage of normal results (-Table 2); and a higher percentage of workers with notch configuration and normal results in post-caloric nystagmus (-Table 3). According to authors, ${ }^{37}$ most drugs are damaging to the cochlea and, to a lesser extent, the vestibule.

In the literature studied, we did not identify research that made similar associations to those described in the previous paragraph, nor studies using VNG as an evaluation method in the population studied. Therefore, we decided to compare the results obtained in this study with those found through other evaluation methods, as well as those of studies with workers exposed to other chemicals considered potentially damaging to the vestibular system.

Authors ${ }^{38}$ evaluating the vestibular system through cephalic auto-rotation in the horizontal plane of patients before and after cisplatin use, concluded that the reduction in the performance of the vestibulo-ocular reflex observed in these patients could be due to chemotherapy, confirming that this instrument is effective for monitoring vestibulotoxicity.

By evaluating workers exposed to organophosphorus compounds, researchers ${ }^{39}$ identified $88 \%$ of alterations of irritative peripheral vestibular syndrome in VNG, nine by changes in caloric tests, with hyperreflexia in absolute values.

Regarding the use of PPE, gloves were the most common equipment, followed by the apron and common mask. Activated carbon masks and goggles, essential equipment for 
handling chemotherapy drugs as they reduce the penetration of aerosols by the worker, ${ }^{23-40}$ are used by a smaller share of the population, and the difficulty of access is the justification reported by the workers in this study. In line with a study ${ }^{41}$ that asked workers about the availability of PPE, we found that $41.80 \%$ of the professionals considered access to these devices as insufficient. These data were also similar to those found in another study, ${ }^{8}$ in which $23.3 \%$ of the nurses surveyed did not use goggles, coal mask, or disposable apron; another study ${ }^{5}$ also identified that $35 \%$ of the subjects did not use goggles.

The use of PPE in the professional practice should be investigated and demanded by supervisors and also by employees. The national literature $e^{42}$ points out that the greater vulnerability of the nursing staff in relation to accidents at work, when compared with staffs of other fields, may be linked to the organizational process and the unavailability of personal protective equipment. While identifying the hazards of exposure to chemotherapy drugs by nurses, a study ${ }^{8}$ observed a higher risk among workers who do not use PPE, or do not use it properly. According to authors, ${ }^{11}$ there is still a low usage of PPE among healthcare professionals, which constitutes a barrier to the adoption of preventive measures.

We found that there is no association between normal and abnormal results in post-caloric nystagmus and use or not of coal mask in the healthcare professions evaluated. The same was true for the occurrence of notch configuration on audiometry and use of PPE (gloves and coal mask).

Although there is no association, one should take into consideration that the professionals who wear gloves achieved a higher incidence of normal results in post-caloric nystagmus, corroborating a study ${ }^{39}$ that linked the possible difference in the outcomes of VNG and non-use of PPE, once $77.8 \%$ of the research subjects who do not use PPE showed changes in vectoelectronystagmography.

In addition, there is a higher incidence of notch in the professionals who did not use coal mask. Researchers ${ }^{9}$ pointed out that exposure to these substances without precautions can cause risk of contact and/or absorption to workers, be it in the activities which involve handling the substance for preparation, in the administration of the drug, or during the contact with excretions of the patient. Authors ${ }^{43}$ detected the presence of antineoplasic drugs in the urine of health professionals who manipulated these drugs without the use of PPE, suggesting that the use of the equipment could prevent such contamination.

It is important to emphasize that the lack of use of PPE may cause the alterations to become even more severe. Due to this, particular attention is needed to the providing of PPE by employers, and its effective usage by workers exposed to chemotherapy drugs when handling, administrating, or applying them, so that possible injuries to the vestibular and hearing health are prevented.

It was possible to notice that the majority of the population studied showed a higher occurrence of normal results on hearing and vestibular evaluation of workers exposed to chemotherapy drugs, but we cannot ignore this small percentage of abnormal findings, since they can provide clinically significant data, especially when used with other procedures.
Furthermore, we believe in the importance of continuing research so as to obtain more information on this topic, once there is a scarcity of studies that discuss it, and the diseases caused by exposure can lead to irreversible consequences for hearing and vestibular health as well as for health conditions in general.

\section{Conclusion}

The pharmacists and nurses exposed to chemotherapy drugs evaluated in this study are mostly young adult women, who have been exposed to the chemical agent at work for less than five years, and who make greater use of gloves, aprons, and common masks as PPE. They have non-rotatory dizziness and neurovegetative symptoms, and anxiety and stress are their most frequent extra-hearing complaints.

Health conditions of the auditory and vestibular systems were within the normal range in most of the evaluated professionals, but with the presence of notch thresholds in pure tone audiometry, commonly identified in workers who reported not having dizziness and had normal caloric test. The association of notch configuration, abnormal caloric test results, and not using coal mask was frequent when compared with the use of gloves; emphasizing the importance of using PPE to maintain the health conditions of these professionals.

\section{References}

1 INCA - Instituto Nacional do Câncer. Estimativa 2014: Incidência de Câncer no Brasil/Instituto Nacional de Câncer José Alencar Gomes da Silva, Coordenação de Prevenção e Vigilância [Internet]. Rio de Janeiro: INCA, 2014. Available at http://www.inca.gov.br/ estimativa/2014/index.asp?ID=2. Acessed August 25, 2015

2 Statistical WHO. Information System (WHOSIS). Cancer. [Denmark]: World Health Organization, Regional Office for Europe; 2010. Available at: http://www.euro.who.int/en/what-we-do/healthtopics/diseases-and-conditions/cancer Accessed May 13, 2014

3 Rombaldi F, Cassini C, Salvador M, Saffi J, Erdtmann B. Occupational risk assessment of genotoxicity and oxidative stress in workers handling anti-neoplastic drugs during a working week. Mutagenesis 2009;24(2):143-148

4 Bonassa EMA. Conceitos gerais em terapia antineoplásica. In: Bonassa EMA, Santana TR, ed. Enfermagem em terapêutica oncológica. São Paulo: Atheneu; 2005:3-19

5 Morais E. Riscos ocupacionais para enfermeiros quando manuseiam quimioterápicos antineoplásicos [dissertation]. Rio de JaneiroUniversidade Federal do Estado do Rio de Janeiro, Centro de Ciências Biológicas e da Saúde2009:73

6 Villarini M, Dominici L, Piccinini R, et al. Assessment of primary, oxidative and excision repaired DNA damage in hospital personnel handling antineoplastic drugs. Mutagenesis 2011;26(3):359-369

7 Saleh JH, Cummings AM. Safety in the mining industry and the unfinished legacy of mining accidents: Safety levers and defensein-depth for addressing mining hazards. Saf Sci 2011;49(6): 764-777

8 Rocha FLR, Marziale MHP, Robazzi MLCC. Potential risks nursing workers are exposed to in handling antineoplastic drugs: know ledge for prevention. Rev Lat Am Enfermagem 2004;12(3):511-517

9 Martins I, Rosa HVD, Della HC. Considerações toxicológicas da exposição ocupacional aos fármacos antineoplásicos. Rev Bras Med Trab 2004;2(2):118-125 
10 Baroni FCAL, Oliveira JCM, Guimarães GL, Matos SS, Carvalho DV. O trabalhador de Enfermagem frente ao gerenciamento de resíduo químico em unidade de quimioterapia antineoplásica. Rev Min Enferm 2013;17(3):554-559

11 Oliveira ADS, Alves AEC, Silva JA, Oliveira SLF, Medeiros SM. Occupational risks of the nursing team's exposure to chemotherapeutic agents: integrative literature review. Rev Enferm UFPE 2013;7(3):788-796

12 Carvalho PR. O ambiente laboratorial. In: Carvalho PR, ed. Boas práticas químicas em biossegurança. Rio de Janeiro: Interciência; 1999:10-26

13 Jacob LCB, Aguiar FP, Tomiasi AA, Tschoeke SN, Bitencourt RF. Monitoramento auditivo na ototoxicidade. Braz J Otorhinolaryngol 2006;72(6):836-844

14 Schacht J, Talaska AE, Rybak LP. Cisplatin and aminoglycoside antibiotics: hearing loss and its prevention. Anat Rec (Hoboken) 2012;295(11):1837-1850

15 Bernardini APA. Testes utilizados na avaliação de trabalhadores expostos a níveis de pressão sonora elevados e solventes. In: Bernardini APA, ed. Conhecimentos essenciais para atuar bem em empresas: audiologia ocupacional. São José dos Campos: Pulso; 2003:67-80

16 Bellé M, Sartori SA, Rossei AG. Alcoholism: effects on the cochleovestibular apparatus. Braz J Otorhinolaryngol 2007;73(1): 106-116

17 Fernandes AS. Estudo das características auditivas e vestibulares em indivíduos expostos ocupacionalmente a mercúrio metálico e ruído [dissertação]. Rio de Janeiro: Universidade Federal do Rio de Janeiro, Instituto de Estudos em Saúde Coletiva; 2009:84

18 Rademaker-Lakhai JM, Crul M, Zuur L, et al. Relationship between cisplatin administration and the development of ototoxicity. J Clin Oncol 2006;24(6):918-924

19 Afifi AK, Bergman RA. Sentidos especiais: correlatos clínicos. In: Afifi AK, Bergman RA, ed. Neuroanatomia Funcional: texto e atlas. São Paulo: Roca; 2008:252-255

20 MT-Ministério do Trabalho [internet]. Brasília: Portal do Trabalho e Emprego; Available at: http://portal.mte.gov.br/data/files/ FF8080812BE914E6012BEF1CA0393B27/nr_09_at.pdf. Accessed Jan 11,2014

21 Marques FP, da Costa EA. Exposure to occupational noise: otoacoustic emissions test alterations. Braz J Otorhinolaryngol 2006; 72(3):362-366

22 Mor T, Fragoso M. Exame vestibular. In: Mor R, Fragoso M, ed. Vestibulometria na prática fonoaudiológica. São Paulo: Pulso; 2012:43-99

23 Odraska P, Dolezalova L, Kuta J, Oravec M, Piler P, Blaha L. Evaluation of the efficacy of additional measures introduced for the protection of healthcare personnel handling antineoplastic drugs. Ann Occup Hyg 2013;57(2):240-250

24 Kemp DT, Ryan S, Bray P. A guide to the effective use of otoacoustic emissions. Ear Hear 1990;11(2):93-105

25 Costa KCF, Silva SMR, Ganança CF. Estudo das provas oculomotoras e vestibulares por meio da vectonistagmografia digital. Distúrb Comum 2005;17(3):315-322

26 Ribeiro EJG, Shimizu HE. Work accidents involving nursing workers. Rev Bras Enferm 2007;60(5):535-540
27 Gondim KM, Miranda MDC, Guimarães JMX, D’alencar BP. Avaliação da prática de ginástica laboral pelos funcionários de um hospital público. Rev Rene 2009;10(2):95-102

28 Silva LF, Reis PED. Avaliação do Conhecimento da Equipe de Enfermagem sobre Riscos Ocupacionais na Administração de Quimioterápicos. Rev Bras Cancerol 2010;56(3):311-320

29 Lima IS, Clementino FS, Miranda FAN, Souza CSM, Brandão ICA Brasil SKD. Equipe de enfermagem: conhecimentos acerca do manuseio de drogas antineoplásicas. Rev Enferm UERJ 2011; 19(1):40-45

30 Schweitzer VG. Ototoxicity of chemotherapeutic agents. Otolaryngol Clin North Am 1993;26(5):759-789

31 Garcia AP, Iório MCM, Petrilli AS. Monitoramento da audição de pacientes expostos à cisplatina. Rev Bras Otorrinolaringol (Engl Ed) 2003;69(2):215-221

32 Amorim AM, Azevedo MF, Carvalho CAF, Macedo CRPD. Emissões Otoacústicas Evocadas por Estímulo Transiente em Crianças Portadoras de Retinoblastoma Submetidas a Tratamento Quimioterápico com Carboplatina. Int Arch Otorhinolaryngol 2007;11(4):375-379

33 Crepaldi de Almeida EO, Umeoka WG, Viera RC, de Moraes IF. High frequency audiometric study in cancercured patients treated with cisplatin. Braz J Otorhinolaryngol 2008;74(3):382-390

34 Ribas A, Schmitz D, Duarte N, Gutierrez L. Achados audiológicos de trabalhadores expostos ao ruído e ao agente químico Arclean SDI. Tuiuti: Cienc Cult 2010;43:23-36

35 Rankel ADC. Roggia Simone. Perfil audiológico de funcionários de uma imprensa universitária [monography]. Florianópolis: Universidade Federal de Santa Catarina, Centro de Ciências da Saúde; 2013:64

36 Azevedo MF. Emissões Otoacústicas. In: Figueiredo MS, ed. Emissões otoacústicas e BERA. São José dos Campos: Pulso; 2003:35-71

37 Silva MLG, Munhoz MSL, Ganança MM, Caovilla HH. Ototoxicoses. In: Silva MLG, Munhoz MSL, Ganança MM, Caovilla HH, ed. Quadros Clínicos Otoneurológicos Mais Comuns. São Paulo: Atheneu; 2000:119-130

38 Kitsigianis GA, O'Leary DP, Davis LL. Active head-movement analysis of cisplatin-induced vestibulotoxicity. Otolaryngol Head Neck Surg 1988;98(1):82-87

39 Hoshino AC, Pacheco-Ferreira H, Taguchi CK, Tomita S, Miranda MdeF. Ototoxicity study in workers exposed to organophosphate. Braz J Otorhinolaryngol 2008;74(6):912-918

40 Manfredo FS, Elias SC. Manipulação de agentes antineoplásicos: a questão da biossegurança. Rev HUPE 2005;4:54-61

41 De Souza RJ. A percepção de profissionais de enfermagem quanto aos riscos ocupacionais que podem gerar doenças/agravos ao seu estado de saúde [dissertation]. Campina Grande: Universidade Estadual da Paraíba, Centro de Ciências Biológicas e da Saúde; 2011:70

42 Santos EI. Vulnerabilidade de enfermeiros no cuidado a pacientes com HIV/Aids: Um estudo de representações sociais [dissertation]. Rio de Janeiro: Universidade do Estado do Rio de Janeiro, Centro Biomédico; 2012:229

43 Clark BA, Sessink PJ. Use of a closed system drug-transfer device eliminates surface contamination with antineoplastic agents. J Oncol Pharm Pract 2013;19(2):99-104 